GELANGGANG PENDIDIKAN JASMANI INDONESIA
Kolume 1, Nomor 1, Tahun 2017

\title{
PENGARUH METODE SMALL SIDED GAMES DAN METODE BAGIAN TERHADAP HASIL BELAJAR PASSING-CONTROL SEPAKBOLA
}

\author{
Dyo Rizky Hadi Soekirno \\ Hariyoko \\ I Nengah Sudjana \\ Fakultas IImu Keolahragaan Universitas Negeri Malang \\ E-mail: dyorizkyhadysoekirno@gmail.com
}

\begin{abstract}
This study aimed to determine the effect of small sided games methods and part methods on learning outcomes passing-control participants extracurricular men's soccer MTs Negeri Srono Kabupaten Banyuwangi aged 13-15 years. The study used a quasi experimental research design with matching ordinal pairing. Samples numbered 24 participants extracurricular men's soccer MTs Negeri Srono Kabupaten Banyuwangi aged 13-15 years. Data analysis technique used is one lane variant analysis. Based on the results of data analysis showed $F_{\text {count }}>F_{\text {table }}(391,32>4,30)$ so that it can concluded part methods gives effect to the learning outcomes soccer passing-control. Learning soccer passing-control using part methods increased learning outcomes soccer passingcontrol.
\end{abstract}

Key words: small sided games method, part method, soccer passing-control.

\begin{abstract}
Abstrak: Penelitian ini bertujuan untuk mengetahui pengaruh metode small sided games dan metode bagian terhadap hasil belajar passing-control peserta ekstrakurikuler sepakbola putra MTs Negeri Srono Kabupaten Banyuwangi usia 13-15 tahun. Penelitian menggunakan rancangan penelitian eksperimen kuasi dengan ordinal pairing matching. Sampel berjumlah 24 peserta ekstrakurikuler sepakbola putra MTs Negeri Srono usia 13-15 tahun. Teknik analisis data yang digunakan adalah Analisis Varian satu jalur. Berdasarkan hasil analisis data menunjukkan $\mathrm{F}_{\text {hitung }}>\mathrm{F}_{\text {tabel }}(391,32>4,30)$ sehingga dapat disimpulkan metode bagian memberikan pengaruh terhadap hasil belajar passingcontrol sepakbola. Pembelajaran passing-control sepakbola menggunakan metode bagian meningkat hasil belajar passing-control sepakbola.
\end{abstract}

Kata kunci: metode small sided games, metode bagian, passing-control sepakbola.

Sepakbola merupakan permainan yang sangat populer di dunia dan tidak terkecuali di Indonesia. Di negara yang kaya akan budaya ini, sepakbola menjadi olahraga yang populer dan merakyat, dari anak-anak hingga orang dewasa sangat menggemari olahraga sepakbola. Olahraga sepakbola sangat mudah dimainkan dan tidak memerlukan banyak mengeluarkan biaya untuk bisa memainkannya. Sepakbola adalah olahraga permainan bola sepak yang dimainkan oleh dua tim dengan masingmasing beranggotakan sebelas orang (AlHadiqie, 2013:9). Dengan peraturan permainan yang mudah, olahraga sepakbola tidak hanya dimainkan oleh kauim laki-laki, tetapi kaum perempuan juga bisa bermain olahraga sepakbola.

Menurut Mielke (2009:19), sepakbola sejatinya adalah permainan tim. Manfaat dan tujuan dari olahraga sepakbola adalah sebagai sarana hiburan, pendidikan, melatih kerjasama atau organisasi, dan prestasi. Tujuan permainan sepakbola adalah untuk mencetak gol sebanyak mungkin yang bisa dilakukan dalam dua babak yaitu babak pertama sampai babak dua berakhir untuk memenangkan satu pertandingan sepak- 
bola. Apabila suatu tim ingin memenangkan pertandingan, sebuah tim sepakbola harus mem-punyai kerjasama yang baik saat pertandingan sepakbola sedang berlangsung. Semua itu dapat diperoleh dari suatu proses pembelajaran sepakbola.

Pembelajaran adalah salah satu cara untuk menciptakan siswa yang terampil dan berprestasi. Pembelajaran merupakan suatu proses belajar untuk memperoleh sebuah pengetahuan, meningkatkan keterampilan atau skil, memperbaiki sikap dan perilaku, serta mengokohkan kepribadian (Suyono, 2011:9). Sedangkan menurut Widijoto (2010:2), pembelajaran adalah upaya memfasilitasi siswa agar menjadi sosok atau individu yang sesuai dengan kompetensi yang diharapkan. Tujuan serta sasaran dari pembelajaran adalah untuk membantu siswa dalam meningkatkan keterampilan belajar dan prestasi belajar hingga semaksimal mungkin. Salah satu keterampilan dasar yang dibutuhkan dalam bermain sepakbola adalah passing-control.

Passing adalah memindahkan momentum bola dari satu pemain ke pemain lain. Passing bola yang baik dilakukan dengan menggunakan kaki, tetapi bagian tubuh lain juga bisa digunakan, seperti kepala dan dada. Passing sepakbola menggunakan kaki bisa dilakukan dengan tiga bagian yaitu passing bola menggunakan kaki bagian dalam, kaki bagian luar, dan kaki bagian dalam. Passing ada dua macam yaitu passing jauh dan passing pendek. Passing bola membutuhkan banyak teknik supaya bisa tetap menguasai bola dan mengendalikan permainan pada saat membangun strategi menyerang. Melakukan control bola (trapping) bisa menggunakan bagian tubuh yang sah seperti, kepala, dada, kaki dan paha. Control (trapping) terjadi ketika seorang pemain menerima passing atau menyambut bola dan mengontrol bola sedemikian rupa sehingga pemain tersebut dapat bergerak dengan cepat untuk melakukan gerakan dribbling, passing, atau shooting (Mielke, 2009:29).

Passing-control merupakan salah satu teknik permainan sepakbola paling dominan yang digunakan untuk bermain sepakbola. Pemain yang memiliki teknik passing-control bola yang bagus akan dapat bermain sepakbola dengan bagus. Oleh sebab itu, pemain sepakbola yang ingin me-mainkan permainan sepakbola harus bisa melakukan dan menguasai teknik dasar sepakbola dengan bagus, khususnya para peserta ekstrakurikuler sepakbola putra yang sedang mengem-bangkan bakatnya.

Salah satu cara yang tepat untuk meningkatkan teknik dasar sepakbola dengan pembelajaran teknik passing-control sepakbola menggunakan metode small sided games dan metode bagian. Pembelajaran passing-control sepakbola dengan metode small sided games dan metode bagian yang sering dijadikan penutup pada tahap pembinaan untuk melatih keterampilan passing-control bola para peserta ekstrakurikuler sepakbola dan melatih akurasi passing-control bola pada saat menyerang atau saat bertahan. Coerver (1987:147), berpendapat bahwa "pada penutup tahap pembinaan yang paling baik adalah permainan dangan seorang pemantul bola atau lebih, karena dengan semangat akan tetap berkobar, sementara peranan dapat ditukar-tukar jika ada yang nampak mulai lelah". Permainan bola untuk penutup materi pembelajaran sepakbola umumnya menggunakan small sided games.

Small sided games adalah setiap permainan yang dimainkan dengan pemain kurang dari sebelas dan di lapangan yang berukuran lebih kecil (Bondarev, 2011:115). Small sided games merupakan bentuk pembelajaran olahraga dalam bentuk permainan lapangan kecil. Small sided games dan metode bagian dapat digunakan dalam penerapan latihan passing sepakbola. Pelaksanaan dalam pembelajaran sepakbola menggunakan metode small sided games maupun metode bagian terdiri dari 7 model formasi bermain.

Model formasi permainan bola pada metode small sided games terdiri dari: (1) Model Drop Pass adalah model small sided games yang paling mudah dipraktikkan. "Passing tidak selalu diarahkan ke gawang dan passing yang bagus adalah drop pass, yang diberikan kepada teman satu tim di belakangmu" Mielke (2009:23). Drop pass dilakukan dengan kecepatan bola yang terukur agar penerima passing tidak susah untuk mengontrol bola. Cara melakukan model drop pass dengan membentuk area bermain 15 x 5 meter dan membentuk dua 
Dyo Rizky Hadi Soekirno, Pengaruh Metode Small Sided Games dan Metode Bagian Terhadap Hasil Belajar Passing-Control Sepakbola

kelompok bermain yang saling berhadapan. Jarak antara pemain yang saling berhadapan adalah 5 meter. Dalam pelaksanaan drop pass melakukan gerakan passing-control bola secara bergantian dari kelompok satu ke kelompok dua, yang sudah melakukan passing berlari pindah posisi ke barisan belakang pemain depan pelaku passing, begitu seterusnya. (2) Model Passing Overlap adalah model permainan bola membentuk model permainan passingcontrol sepakbola dengan melakukan umpan atau passing bola dengan membentuk area bermain 10 × 10 meter. Menurut Mielke (2009:23) passing overlap adalah "passing yang digunakan untuk menciptakan ruang dengan meng-gunakan gerakan lari overlap". Maksud dari lari overlap adalah pemain penyerang mengoperkan bola ke teman satu timnya, kemudian dia akan berlari mengikuti garis lengkung melewati penerima passing dan berada di depan lagi untuk menerima bola lagi. Ketika melakukan pembelajaran passing overlap ini, peserta ekstrakurikuler yang melakukan passing akan memberikan bola kepada pasangan bermainnya dan bergerak ke ruang yang terbuka atau ruang yang kosong di samping peserta yang menerima passing. Setelah melakukan passing, pemain tersebut langsung berlari melewati pemain yang menerima passing dan meminta diberi passing overlap. (3) Model Passing Give-and-Go adalah permaianan passing sepakbola denagn melakukan passing-control sepakbola yang mem-punyai misi untuk memberi peluang bagi seorang pemain melakukan passing kepada teman satu tim dan selanjutnya berlari ke depan, lalu pemain yang menerima passing dengan cepat mengembalikan bola kepada pemain pertama ketika mereka bersama-sama bergerak maju kedaerah lain didalam area lapangan permainan. Tujuan dari teknik per-mainan passing give-and-go adalah untuk menghindari lawan yang akan merebut bola dari penguasaan kita dan bergerak di lapangan secara cepat saat permainan sepakbola berlangsung. Passing give-and-go mengharuskan peserta permainan yang mengoperkan bola kepada penerima bola yang kemudian berlari cepat ke arah depan. Selanjutnya penerima bola kemudian segera mengembalikan passing bola tersebut tanpa menghentikan laju bola dengan meng- gunakan satu sentuhan kaki untuk mengarahkan laju bola ke arah pemain pertama yang telah bergerak ke depan. Area bermain permainan passing give-and-go $15 \times 15$ meter. (4) Model 3 vs 1 merupakan permainan passing-control sepakbola dengan membuat model permainan passingcontrol sepakbola dengan membentuk area bermain berpola segi tiga dengan ukuran lapangan 10 x 10 meter. Dalam pelaksanaannya, model small sided games 3 vs 1 menempatkan empat orang pemain dalam area bermain yang sudah dibuat. Tiga orang membentuk tim pemegang bola (melakukan passing bola). Satu pemain di tengah sebagai perebut bola. Dalam pelaksanaannya formasi permainan ini tim bermain 3 vs 1 , dengan target menguasai bola selama mungkin bagi tim yang menguasai bola dengan melakukan passing 2 kali sentuhan bola. Apabila perebut bola di tengah berhasil merebut bola, pemain yang melakukan salah passing bertukar posisi dan menjadi perebut bola di tengah. (5) Model 4 vs 2 adalah permainan passing-control sepakbola dengan membuat model permainan menbentuk pola lapangan bermain berbentuk segi empat dengan ukuran lapangan 15 x 15 meter. Dalam pelaksanaan permainan passing-controi sepakbola 4 vs 2 dengan menempatkan enam orang pemain di dalam area permainan yang sudah dibuat. Dan empat orang pemain membentuk tim yang bertugas sebagai pemegang bola (melakukan passing-control sepakbola), dan dua pemain di tengah bertugas sebagai pemain perebut bola dari tim pemegang bola. Dalam pelaksanaannya formasi bermain ini tim bermain 4 vs 2, dengan target menguasai bola selama mungkin bagi tim yang menguasai bola dengan melakukan passing 2 kali sentuhan bola. Apabila pemain perebut bola di tengah berhasil merebut bola dari kaki salah satu pemain pengumpan bola, pemain dari tim pengumpan bola yang melakukan salah passing bertukar posisi menggantikan peran dari pemain perebut bola di tengah sebelumnya. (6) Model 4 vs $(2+2)$ adalah permainan passing-control sepakbola dengan membuat model permainan membentuk area bermain berbentuk segi empat dengan ukuran lapangan $15 \times 15$ meter dengan satu gawang saja selebar satu meter. Dalam pelaksanaan model 4 vs $(2+2)$ 
dengan menempatkan delapan pemain di dalamnya, dari delapan pemain dibagi menjadi dua tim. Tim satu bertugas sebagai penyerang, tim kedua bertugas berbagi tugas dua orang sebagai pemain bertahan merebut bola dari pemain penyerang dan dua orang pemain bertugas menjaga gawang tidak diper-bolehkan menyentuh bola dengan tangan. Tim yang melakukan serangan berusaha mencetak gol dengan menggunakan passing. Apabila tim bertahan merebut bola, kedua penjaga gawang langsung naik menyerang. Dua orang pemain dari tim passing yang bolanya bisa direbut harus turun menjadi penjaga gawang begitu seterusnya untuk menggantikan pemain yang bertugas menjadi penjaga gawang sebelumnya. (7) Model 2 vs $2+4$ Netral adalah permainan passing sepakbola dengan membuat model permainan membentuk area bermain berbentuk segi empat dengan ukuran lapangan $20 \times 20$ meter. Diantara sudut area permainan diberi pembatas (cone). Dalam pelaksanaan permainan passing-control 2 vs $2+4$ netral dengan membentuk dua tim, tim satu dan dua masing-masing dua orang pemain, dan tambah empat pemain netral sebagai tembok yang posisinya berada diantara tengah-tengah batas area permainan (cone). Dalam pelaksanaannya, formasi 2 vs $2+4$ netral peserta sebagai tembok diperbolehkan bergerak sepanjang garis area permainan passing. Peserta sebagai tembok hanya diperbolehkan melakukan teknik passing dengan satu sentuhan kaki saja. Tambah tingkat kesulitan dengan membatasi per-mainan dengan dua sentuhan.

Metode bagian merupakan metode permainan yang bisa digunakan untuk pembelajaran di beberapa cabang olahraga bola kecil maupun olahraga bola besar, salah satunya bisa digunakan dalam olahraga sepakbola. Metode bagian adalah metode pembelajaran yang dilakukan dari bagian yang sederhana ke yang kompleks secara keseluruhan, dari yang umum ke yang khusus, dilaksanakan dari mempelajari bagian dasar, dan disusun dari bagian yang mudah ke yang sulit.

Model formasi pembelajaran passingcontrol sepakbola metode bagian terdiri dari: (1) Model back pass 3 meter adalah model permainan passing-control sepakbola de- ngan memberikan tugas kepada peserta ekstrakurikuler sepakbola untuk melakukan pembelajaran back pass dengan masingmasing pasangan pemain melakukan passing-control bola secara bergantian dengan jarak masing-masing pasangan 3 meter. (2) Model back pass 10 meter adalah permainan passing-control sepakbola dengan memberikan perlakuan praktek pembelajaran teknik passing-control sepakbola kepada pemain dengan menggunakan permainan variasi back pass. Pada pelaksanaannya, peserta ekstrakurikuler sepakbola diposisikan membentuk dua kelompok berbaris menyamping berpasangan dan saling berhadapan untuk melakukan back pass dengan jarak masing-masing pasangan 10 meter. Dengan luas area permainanan 10 x 10 meter. Cara melakukan pembelajaran permainanan back pass dengan masingmasing pasangan melakukan passingcontrol bola secara bergantian. (3) Model drop pass 5 meter adalah permainan passing-control sepakbola dengan memberi perlakuan gerak pembelajaran passingcontrol sepakbola meng-gunakan permainan variasi back pass. Peserta diposisikan membentuk dua kelompok barisan dengan posisi saling berhadapan dengan area bermain $15 \times 2$ meter. Tahapan yang harus dilakukan pemain untuk melakukan permainan dengan peserta barisan paling depan kelompok B melakukan passing ke arah peserta barisan paling depan kelompok A. Setelah peserta barisan paling depan kelompok $B$ melakukan passing ke arah peserta barisan paling depan kelompok $A$, dilanjutkan dengan berlari ke barisan paling belakang di kelompok B. Peserta ke dua, ke tiga, ke empat, ke lima, dan ke enam kelompok B maju satu langkah ke depan. Peserta barisan paling depan kelompok $A$ menerima passing dari peserta kelompok $\mathrm{B}$ dengan mengontrol bola dan me-lanjutkan melakukan pasing ke arah pemain barisan paling depan kelompok B. Setelah peserta barisan paling depan kelompok $A$ melakukan passing ke arah peserta barisan paling depan kelompok $\mathrm{B}$, dilanjutkan dengan berlari kebarisan paling belakang di kelompok A. Pesrta ke dua, ke tiga, ke empat, ke lima, dan ke enam ke lompok $A$ maju satu langkah ke depan. Begitu seterusnya. (4) Model drop pass 10 meter 
Dyo Rizky Hadi Soekirno, Pengaruh Metode Small Sided Games dan Metode Bagian Terhadap Hasil Belajar Passing-Control Sepakbola

adalah permainan passing-contro/ sepakbola menggunakan permainan variasi back pass. Cara melakukan permainan ini dengan memposisikan pemain membentuk dua kelompok barisan yang saling berhadapan dengan area bermain $20 \times 2$ meter. Peserta barisan paling depan kelompok $B$ melakukan passing ke arah peserta barisan paling depan kelompok A. Setelah peserta barisan paling depan kelompok $B$ melakukan passing ke arah peserta barisan paling depan kelompok A, dilanjutkan dengan berlari kebarisan paling belakang di kelompok B. Pesrta ke dua, ke tiga, ke empat, ke lima, dan ke enam kelompok B maju satu langkah ke depan. Peserta barisan paling depan kelompok A menerima passing dari peserta kelompok $\mathrm{B}$ dengan mengontrol bola dan melanjutkan melakukan pasing kearah pemain barisan paling depan kelompok B. Setelah peserta barisan paling depan kelompok A melakukan passing kearah peserta barisan paling depan kelompok $\mathrm{B}$, dilanjutkan dengan berlari ke barisan paling belakang di kelompok $A$. Peserta ke dua, ke tiga, ke empat, ke lima, dan ke enam kelompok A maju satu langkah ke depan. Begitu seterusnya. (5) Model variasi drop pass 1 adalah permainan passing-control dengan praktek pembelajaran passing-control menggunakan permainan variasi back pass. Cara melakukan permainan ini adalah dengan mem-posisikan pemain membentuk dua kelompok barisan yang saling berhadapan dan 1 peserta di tengah antara dua kelompok dengan area bermain $2 \times 22$ meter. Peserta ekstrakurikuler yang posisi terdepan mengawali dengan melakukan passing ke arah peserta ekstrakurikuler di depannya. Setelah melakukan passing peserta ekstrakurikuler berlari ke tengah antara jarak mereka berhadapan untuk menunggu menerima back pass dari peserta lawan hadapnya dengan mengontrol bola dan untuk selanjutnya berlari ke barisan belakang. Dengan cara dan gerakan yang sama melakukan variasi back pass passing-control model 5 dilakukan bigutu seterusnya secara bergantian antar dua kelompok barisan. (6) Model variasi drop pass 2 adalah permainan passingcontrol sepakbola menggunakan per-mainan variasi back pass. Cara melakukan permainannya dengan membentuk dua kelompok barisan yang saling berhadapan dan 1 peserta di tengah antara dua kelompok dengan area bermain $2 \times 22$ meter. Peserta ekstrakurikuler yang posisi terdepan pada masing-masing barisan pemain a/pemain ke-1 mengawali dengan melakukan passing kearah peserta ekstrakurikuler di depannya pemain $\mathrm{f} /$ pemain ke-6. Peserta pemain f/pemain ke-6 menghentikan bola dengan trapping, selanjutnya pemain $\mathrm{f}$ berlari pindah posisi di belakang pemain ke-5, sebaliknya pemain ke-6 berlari pindah posisi di belakang pemain e. Pemain a berlari pindah posisi ke posisi pemain f sebelumnya dan melakukan back pass ke pemain $b$, demikian sama dengan pemain ke-1 berlari pindah ke posisi pemain ke-6 sebelumnya dan melakukan back pass kearah pemain ke-2. Demikian dengan pemain selanjutnya melakukan dengan cara yang sama melakukan praktik pembelajaran passing-control tersebut. (7) Model back pass formasi lingkaran adalah permainan passing-control sepakbola menggunakan model permainan variasi back pass dengan membentuk formasi barisan melingkar. Untuk melakukan pembelajaran peserta diposisikan membentuk barisan melingkar dan 1 peserta di tengah. Dengan area bermain $15 \times 15$ meter. Peserta membentuk formasi melingkar, satu orang berada di tengah. Peserta ke-1 melakukan passing kepada peserta ke-12 yang berada di tengah lingkaran, dan lari berganti posisi ke tengah lingkaran. Peserta ke-12 menerima passing dengan mengontrol bola, dan melanjutkan melakukan passing kepada peserta ke-2, Ber-samaan dengan peserta ke-1 yang berlari ke tengah lingkaran peserta ke-12 berlari pindah keposisi peserta ke-2. Dengan cara bermain yang sama untuk peserta ke-2 dan peserta seterusnya melakukan cara bermain yang sama secara bergantian.

Dengan pentingnya teknik dasar passing-control bola pada permainan sepakbola maka perlu adanya metode khusus yang efektif untuk mening-katkan keterampilan dasar bermain sepakbola, seperti halnya para pemain profesional ditingkat nasional ataupun internasional yang memiliki kemam-puan passing-control bola yang sangat bagus. Metode khusus yang efektif untuk meningkatkan keterampilan dasar sepakbola bisa menggunakan metode small sided games dan metode bagian. Hanya sedikit penelitian yang mengenai passing- 
control sepakbola, akan tetapi banyak pelatih sepakbola yang telah menggunakan metode small sided games dan motode bagian dalam pembelajaran ekstrakurikuler sepak-bola.

Ekstrakurikuler merupakan kegiatan di luar jam sekolah yang digunakan untuk mengembangkan bakat siswa dalam cabang olahraga tertentu. Ekstrakurikuler sepakbola adalah suatu wadah untuk mening-katkan bakat siswa dalam cabang olahraga sepakbola. Hasil pengamatan langsung di lapangan yang bertempat di Kecamatan Srono Kabupaten Banyuwangi Berdasarkan pengamatan yang dilakukan oleh peneliti pada proses pembelajaran sepakbola pada ekstrakurikuler sepakbola putra MTs Negeri Srono Kabupaten Banyuwangi, diketahui bahwa (1) dari 24 pemain, setiap pemain melakukan heading sebanyak 20 kali, 80\% diantaranya melakukan dengan benar, (2) dari 24 pemain melakukan tes shooting $80 \%$ siswa melakukan dengan baik (3) dari 24 pemain melakukan dribbling, $90 \%$ pemain sudah baik, (4) dari 24 pemain melakukan passing-control sebanyak 18 kali, 45\% diantaranya melakukan dengan benar tapi kurang tepat sasaran. Jadi peneliti mengambil kesimpulan bahwa hasil observasi dari beberapa aspek tersebut yang paling rendah persentasenya adalah passing-control. Untuk dapat mengembangkan hasil belajar passing-control dapat dilakukan dengan menerapkan metode small sided games dan metode bagian.

Berdasarkan analisis kebutuhan pada proses pembelajaran sepakbola pada ekstrakurikuler sepakbola putra MTs Negeri Srono Kabupaten Banyuwangi, diketahui bahwa (1) dari 24 pemain, setiap pemain melakukan heading sebanyak 20 kali, 80\% diantaranya melakukan dengan benar, (2) dari 24 pemain melakukan tes shooting $80 \%$ siswa melakukan dengan baik (3) dari 24 pemain melakukan dribbling, $90 \%$ pemain sudah baik, (4) dari 24 pemain melakukan passing-control sebanyak 18 kali, 45\% diantaranya melakukan dengan benar tapi kurang tepat sasaran. Jadi peneliti mengambil kesimpulan bahwa hasil observasi dari beberapa aspek tersebut yang paling rendah persentasenya adalah passing-control. Passing-control tidak bisa dilakukan hanya dengan benar saja, tetapi juga perlu adanya pendukung lain seperti metode belajar dan model pembelajaran, sehingga pada saat melakukan passing peluang untuk membuka ruang gerak dan membangun serangan untuk mencetak gol ke gawang lawan, untuk dapat meningkatkan hasil belajar dapat dilakukan dengan menerapkan metode small sided games dan metode bagian.

Hasil penelitian terdahulu dari Putra (2015), latihan small sided games terhadap kemampuan $\mathrm{VO}_{2} \mathrm{MAX}$ pemain sepakbola U17 di persatuan sepakbola SMUBA junior Kota Batu memberikan pengaruh yang lebih baik dibandingkan latihan konvensional.

Berdasarkan masalah yang telah dipaparkan tersebut, maka peneliti telah melakukan penelitian dengan judul "Pengaruh Metode Small Sided Games dan Metode Bagian Terhadap Hasil Belajar Passing-Control Sepakbola". Tujuan penelitian ini adalah untuk mengetahui dan mengkaji perbedaan pengaruh metode small sided games dan metode bagian terhadap hasil belajar passing-control peserta ekstrakurikuler sepakbola putra MTs Negeri Srono Kabupaten Banyuwangi usia 13-15 tahun.

\section{METODE}

Rancangan dalam penelitian eksperimen ini adalah matching pre-test posttest control grup design (Sukmadinata, 2013:207). Dalam rancangan ini terdapat dua kelompok yang dipilih secara dipasangkan (matching paired) sesuai dengan hasil tes awal (pre-test). Variabel bebas yang dimanipulasi dalam penelitian ini adalah metode small sided games dan metode bagian, serta variabel terikatnya adalah hasil belajar keterampilan passingcontrol sepakbola.

Penelitian ini dilaksanakan pada bulan Februari-Maret 2016 dengan tahapantahapan sebagai berikut: (1) Testi berdiri di belakang garis batas dan siap untuk melakukan passing-control bola yang diletakkan di belakang garis batas. Garis batas berada sejajar dengan papan pantul dengan jarak 2.0 meter. (2) Setelah aba-aba "YA", testi melakukan passing-control bola ke arah sasaran yang ada di papan pantul, lalu mengontrol bola yang memantul, dan melakukannya berulang kali selama 30 detik. 
Dyo Rizky Hadi Soekirno, Pengaruh Metode Small Sided Games dan Metode Bagian Terhadap Hasil Belajar Passing-Control Sepakbola

(3) Pada saat pelaksanaan tes, testi dan bola harus tetap berada pada atau di belakang garis batas. Juga, disediakan tiga bola, satu bola ditempatkan pada awal tes, dan dua bola lainnya ditempatkan 5 meter di belakang garis batas. (4) Testi diperbolehkan meng-gunakan kaki atau bagiang kaki/badan manapun yang lebih disukai untuk melakukan passing dan mengontrol bola. (5) Testi dianggap melakukan tes dengan tidak benar apabila: melakukan passing dan mengontrol bola tidak sesuai ketentuan, memainkan dan menguasai bola dengan lengan/tangan.

Populasi penelitian adalah pe-serta ekstrakurikuler sepakbola putra MTs Negeri Srono Kabupaten Banyuwangi usia 13-15 tahun. Pengambilan sampel menggunakan simple random sampling (Sugiyono, 2015: 120), dimana pengambilan anggota sampel dari populasi dilakukan secara acak (random). Sampel dari penelitian ini adalah peserta ekstra-kurikuler sepakbola putra usia 13-15 tahun sebanyak 24. Dari sampel 24 peserta, 12 peserta masuk ke kelompok small sided games dan 12 peserta masuk ke kelompok metode bagian. Pembagian kelompok untuk setiap kelompok eksperimen sejumlah 12 peserta dilakukan dengan teknik ordinal pairing matching (Hadi, 2004:485).

Instrumen yang digunakan dalam penelitian berupa instrumen tes dan non tes untuk menyimpulkan data variabel, dan instrumen non tes berupa observasi. Instrumen metode small sided games dan metode bagian menggunakan program pembelajaran metode small sided games dan program pembelajaran metode bagian passing-control sepakbola, sedangkan instrumen tes hasil belajar keterampilan passing-control sepakbola peserta ekstrakurikuler sepakbola putra MTs Negeri Srono Kabupaten Banyuwangi usia 13-15 tahun menggunakan tes keterampilan dasar passing-control bola (Hariyoko, 2012:351).

Pengumpulan data meng-gunakan teknik eksperimen dan teknik pengukuran bentuk tes keterampilan passing-control sepakbola. Tahap pengumpulan meliputi tahap pre-test, treatment, post-test. Tahap pelak-sanaan pengumpulan data meliputi tahap persiapan (studi kepustakaan, surat ijin penelitian, menyusun instrumen tes, sarana prasarana penelitian, arahan kepada subjek penelitian), tahap pelaksanaan (melakukan tes awal passing-control terhadap kedua kelompok, melakukan tes akhir passing-control terhadap kedua kelompok). Tahap pelaporan hasil penelitian menyampaikan kegiatan dari awal hingga akhir pelaksanaan perlakuan selamaselama 6 minggu. Berdasarkan rumusan tujuan penelitian dan dengan pertimbangan jenis data yang terkumpul dari tes ketepatan passing-control seapakbola berupa data rasio, maka data yang diperoleh dianalisis dengan menggunakan teknik analisis varian satu jalur atau analisis varians (uji F) (Sugiyono, 2013:166). Harga F hitung dibandingkan dengan $F$ tabel pada taraf signifikansi $5 \% \quad(\alpha=0,05)$. Sebelum pengujian hipotesis dengan analisis varian satu jalur, terlebih dahulu dilakukan uji persyaratan yaitu uji normalitas menggunakan teknik Liliefors (Nurrochmah 2005) dan uji homogenitas menggunakan teknik Levene (Nurrochmah 2005) untuk mengetahui apakah data tersebut berdistribusi normal dan homogen atau tidak pada masing-masing kelompok penelitian. Berikutnya adalah dengan melakukan uji hipotesis dengan menggunakan analisis varian satu jalur dilakukan dengan taraf signifikasi $\alpha=0,05$. Pengujian hipotesis menggunakan taraf signifikasi $5 \%(\alpha=0,5)$.

\section{HASIL}

Data hasil tes keterampilan passingcontrol sepakbola yang di-gunakan untuk analisis adalah mean skor hasil tes awal (pre-test) dan tes akhir (post-test) hasil belajar keterampilan passing-control sepakbola peserta ekstrakurikuler sepakbola putra MTs Negeri Srono Kabupaten Banyuwangi. Banyak sampel pada setiap kelompok adalah 12 peserta ekstrakurikuler sepakbola putra usia 13-15 tahun. Berdasarkan ratarata skor pre-test keterampilan passing kelompok small sided games adalah 20,08 dan post-test keterampilan passing-control adalah 21,91. Dan diperoleh simpangan baku dari pre-test keterampilan passingcontrol kelompok metode small sided games sebesar 0,99 dan post-test keterampilan passing-control sebesar 1,31. Ber-dasarkan hasil pre-test kelompok metode small sided games skor minimal keterampilan passing- 
control 18 dan post-test skor minimal keterampilan passing-control sebesar 20. Berdasarkan hasil pre-test kelompok metode small sided games skor maximal keterampilan passing-control 21 dan post-test skor maximal keterampilan passing-control sebesar 24.

Berdasarkan rata-rata skor pre-test keterampilan passing kelompok metode bagian adalah 19,83 dan post-test keterampilan passing-control adalah 22,41 Dan diperoleh simpangan baku dari pre-test keterampilan passing-control kelompok metode bagian sebesar 1,11 dan post-test keterampilan passing-control sebesar 1,16. Berdasarkan hasil pre-test kelompok metode bagian skor minimal keterampilan passing-control 18 dan post-test skor minimal keterampilan passing-control sebesar 21. Ber-dasarkan hasil pre-test kelompok metode bagian skor maximal keterampilan passing-control 21 dan post-test skor maximal keterampilan passing-control sebesar 24 .

Sebelum dilakukan pengujian hipotesis dengan analisis varians (ANAVA) satu jalur, terlebih dahulu dilakukan uji persyaratan analisis varians, yaitu uji normalitas dan uji homogenitas. Dasar pengambilan keputusan uji normalitas metode Lilliefors dengan menggunakan nilai statistik uji Lilliefors (Sudjana, 2005:466) pada taraf signifikansi a $=0,05$.

Berdasarkan data tes awal (pre-test) hasil tes passing-control kelompok metode small sided games peserta ekstrakurikuler sepakbola putra MTs Negeri Srono Kabupaten Banyuwangi usia 13-15 tahun dengan instrumen tes passing-control sepakbola didapatkan rentangan skor 18 sampai dengan 24, sedangkan rata-rata (mean) sebesar 20,08 dan simpangan baku (SD) sebesar 0,99. Dari data tes awal passingcontrol kelompok metode small sided games diketahui bahwa 9 peserta berada di kelas interval rata-rata skor tes. Sedangkan 3 peserta berada pada kelas interval di bawah kelas interval rata-rata hasil skor tes. Sejalan dengan hasil analisis data dalam bentuk Histogram 1.

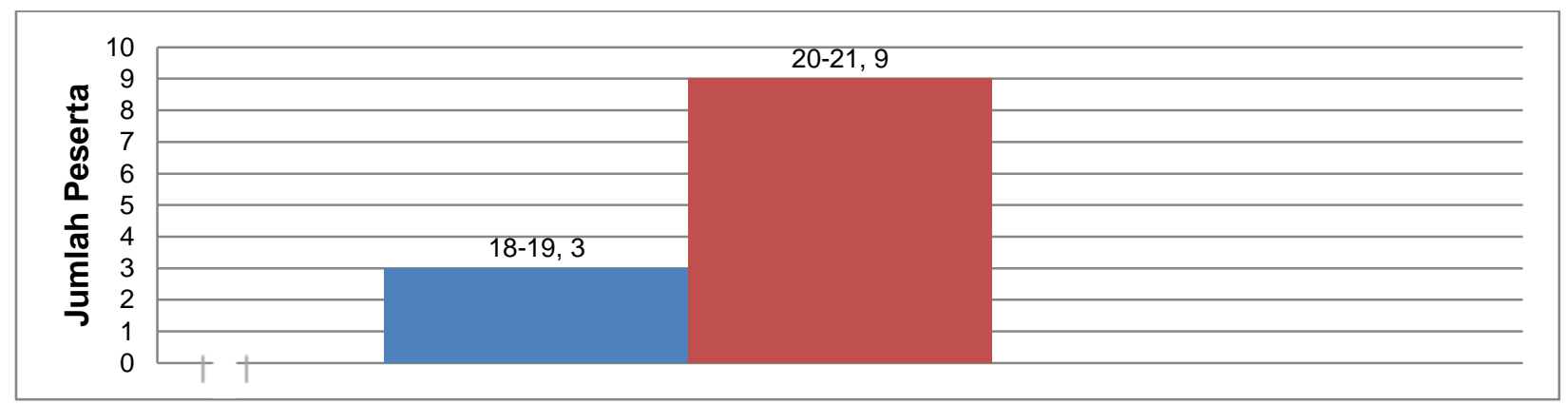

Gambar 1. Histogram Hasil Skor Tes Awal Passing-Control Sepakbola Kelompok Metode Small Sided Games

Berdasarkan data hasil tes akhir (posttest) passing-control sepakbola kelompok metode Small sided games peserta ekstrakurikuler sepakbola putra MTs Negeri Srono Kabupaten Banyuwangi usia 13-15 tahun dengan instrumen tes passing-control sepak-bola didapatkan rentangan skor 20 sampai dengan 24, didapatkan rata-rata (mean) sebesar 21,91, sedangkan simpangan baku (SD) sebesar 0,99. Dari data tes akhir passing-control kelompok metode small sided games passing-control kelompok metode small sided games diketahui bahwa 5 peserta yang berada di bawah kelas interval rata-rata skor tes. Sedangkan 7 peserta berada di kelas interval diatas kelas interval rata-rata skor tes. Sejalan dengan hasil analisis data dalam bentuk Histogram 2. 
Dyo Rizky Hadi Soekirno, Pengaruh Metode Small Sided Games dan Metode Bagian Terhadap Hasil Belajar

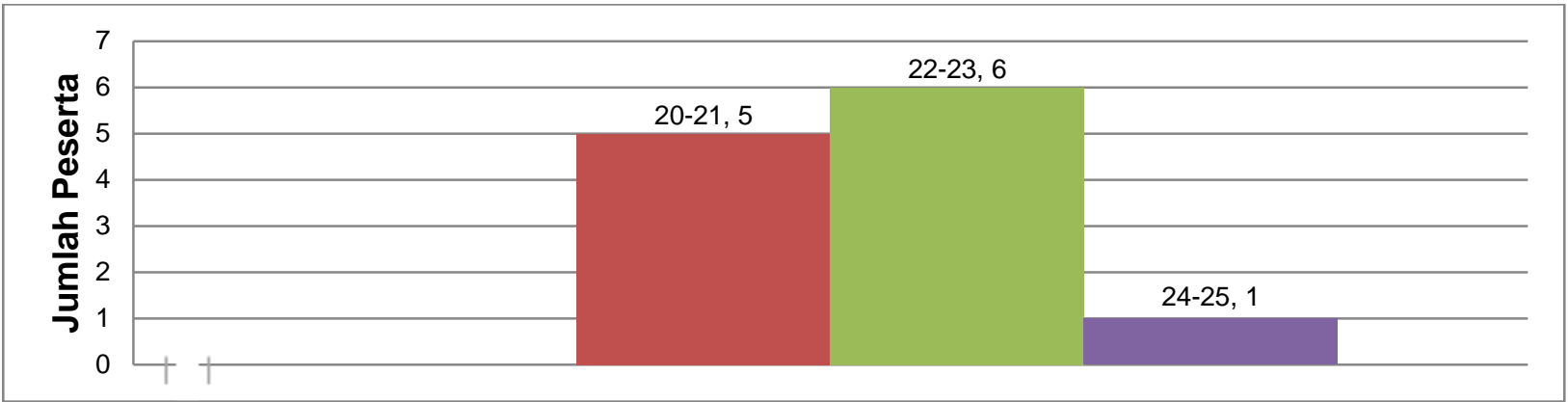

Gambar 2. Histogram Hasil Skor Tes Akhir Passing-Control Sepakbola Kelompok Metode Small Sided Games

Berdasarkan data hasil tes awal (pretest) passing-control sepakbola kelompok metode bagian peserta ekstrakurikuler sepakbola putra MTs Negeri Srono Kabupaten Banyuwangi usia 13-15 tahun dengan instrumen tes passing-control sepakbola didapatkan rentangan skor 18 sampai dengan 21, didapatkan rata-rata (mean) sebesar 19,83, sedangkan simpangan baku (SD) sebesar 1,11. Dari data tes awal passing-control kelompok metode bagian diketahui bahwa 8 peserta berada di atas kelas interval rata-rata

skor tes. Sedangkan 4 peserta berada di bawah kelas interval rata-rata skor tes. Sejalan dengan hasil analisis data hasil tes awal (pre-test) passing-control sepakbola kelompok metode bagian peserta ekstrakurikuler sepakbola putra MTs Negeri Srono Kabupaten Banyuwangi usia 13-15 tahun dalam bentuk Histogram 3 .

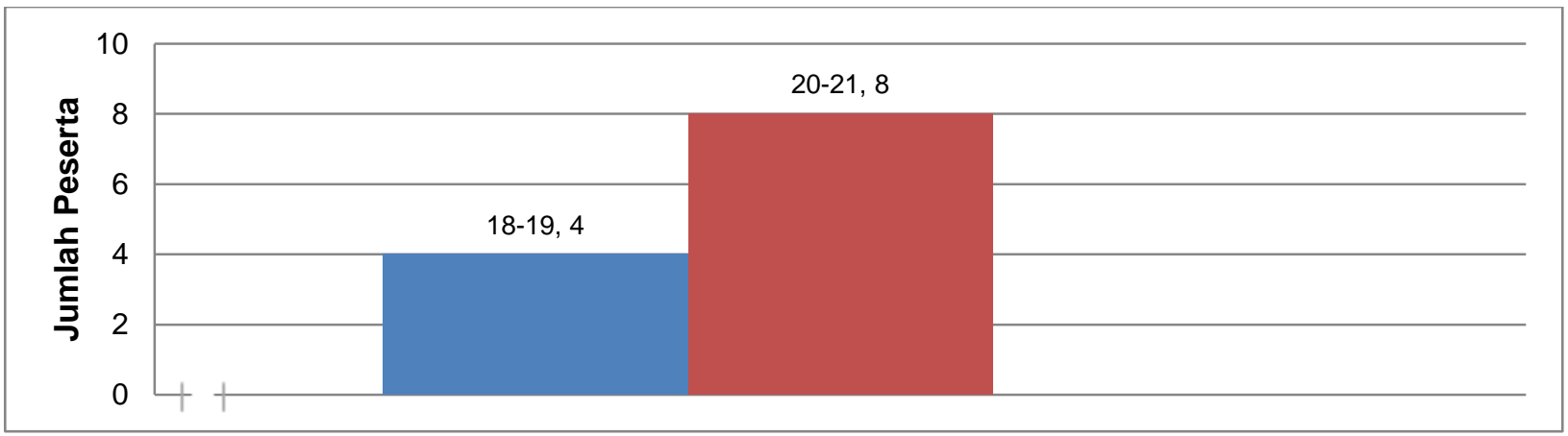

Gambar 3. Histogram Hasil Skor Tes Awal Passing-Control Sepakbola Kelompok Metode Bagian

Berdasarkan data hasil tes akhir (posttest) passing-control sepakbola kelompok metode bagian peserta ekstrakurikuler sepakbola putra MTs Negeri Srono Kabupaten Banyuwangi usia 13-15 tahun dengan instrumen tes passing-control sepakbola didapatkan rentangan skor 21 sampai dengan 24 didapatkan rata-rata (mean) sebesar 22,41, sedangkan simpangan baku (SD) sebesar 1,16. Dari data tes awal passing-control kelompok metode bagian diketahui bahwa 9 peserta berada di atas kelas interval rata-rata skor tes. Sedangkan 3 peserta berada di bawah kelas interval rata-rata skor tes. Sejalan dengan hasil analisis data dalam bentuk Histogram 4.

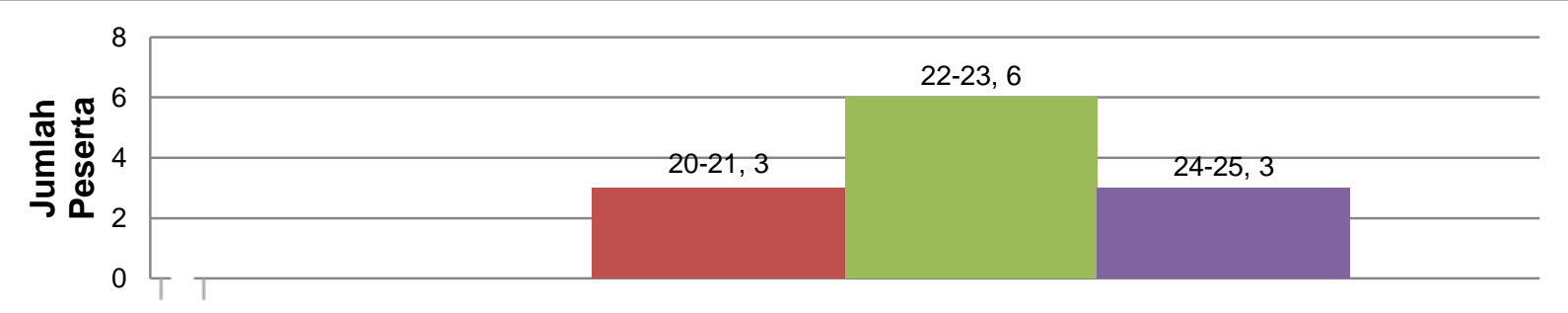

Gambar 4. Histogram Hasil Skor Tes Akhir Passing-Control Sepakbola Kelompok Metode 
Berdasarkan hasil uji normalitas mean skor tes awal dengan tes akhir hasil belajar keterampilan passing yang dilakukan pada masing-masing kelompok metode pembelajaran jumlah sampel adalah 12 peserta ekstra-kurikuler sepakbola putra usia 13-15 tahun. Dari kelompok 1 hasil ke-terampilan passing-control tes awal kelompok small sided games $L_{\text {hitung }} 0,1788, L_{\text {tabel }} 0,242$ dengan keterangan uji normalitas normal. Dari kelompok 2 hasil keterampilan passingcontrol tes akhir kelompok small sided games $L_{\text {hitung }} 0,12723, L_{\text {tabel }}$ 0,242 dengan keterangan uji normalitas normal. Dari kelompok 3 hasil keterampilan passingcontrol tes awal kelompok me-tode bagian $L_{\text {hitung }} 0,13903, L_{\text {tabel }} 0,242$ dengan keterangan uji normalitas normal. Dari kelompok 4 hasil ke-terampilan passing-control tes akhir kelompok metode bagian $L_{\text {hitung }}$ $0,07817, L_{\text {tabel }} 0,242$ dengan keterangan uji normalitas normal.

Berdasarkan hasil perhitungan uji normalitas diperoleh harga $L_{\text {hitung }}$ untuk setiap kelompok lebih kecil jika dibandingkan dengan $L_{\text {tabel }}$ taraf signifikansi $\alpha=0,05$. Dengan demikian dapat disimpulkan bahwa seluruh kelompok berasal dari populasi yang berdistribusi normal.

Uji homogenitas dengan meng-gunakan uji Levene (Sugiyono, 2013:140) dilakukan terhadap mean skor tes awal dan tes akhir keterampilan passing masing-masing kelompok metode pembelajaran dengan menggunakan uji $F$ pada taraf signifikansi $\alpha=0,05$.

Pada masing-masing kelompok metode pembelajaran jumlah sampel adalah 12 peserta ekstrakurikuler sepakbola putra usia 13-15 tahun. Dari hasil skor tes awal dan tes akhir passing-control kelompok metode small sided games didapatkan $F_{\text {hitung }} 1,7328$, dan $\mathrm{F}_{\text {tabel }} 4,30$ dengan keterangan homogen. Dan hasil skor tes awal dan tes akhir passing-control kelompok metode baigian didapatkan $F_{\text {hitung }} 1,0914$, dan $F_{\text {tabel }} 4,30$ dengan keterangan homogen.

Berdasarkan hasil perhitungan uji homogenitas diperoleh harga $F_{\text {hitung }}$ untuk seluruh kelompok lebih kecil jika dibandingkan dengan $F_{\text {tabel }}$ taraf signifikansi $\alpha=0,05$. Dengan demikian dapat disimpulkan bahwa seluruh kelompok berasal dari populasi yang homogen.
Setelah uji persyaratannya dapat terpenuhi, kemudian dilakukan peng-ujian hipotesis dengan menggunakan teknik analisis varian (ANAVA) satu jalur (Sugiyono, 2013:166) pada taraf signifikansi $\alpha=0.05$. Pengujian hipotesis yang pertama dengan analisis varians satu jalur dilakukan terhadap data hasil belajar ke- terampilan passing-control tes awal dengan tes akhir kelompok metode small sided games.

Berdasarkan hasil perhitungan analisis varian skor hasil belajar keterampilan passing-control kelompok metode small sided games diperoleh harga $F_{\text {hitung }} 14,93$ untuk skor hasil tes passing-control sepakbola lebih besar jika dibandingkan dengan $F_{\text {tabel }} 4,30$ taraf signifikansi $\alpha=0,05$. Dengan demikian dapat disimpulkan bahwa ada pengaruh yang signifikan antara hasil tes awal dengan tes akhir passing-control sepakbola kelompok metode small sided games.

Uji hipotesis kedua mengetahui pengaruh metode bagian terhadap hasil belajar keterampilan passing-control peserta ekstrakurikuler sepakbola putra MTs Negeri Srono Kabupaten Banyuwangi. Hasil perhitungan uji analisis varians satu jalur hasil belajar keterampilan passing-control tes awal dengan tes akhir kelompok metode bagian.

Berdasarkan hasil perhitungan analisis varian diperoleh harga $F_{\text {hitung }} 27,88$ untuk skor hasil tes passing-control sepakbola lebih besar jika dibandingkan dengan $F_{\text {tabel }}$ 4,30 taraf signifikansi $\alpha=0,05$. Dengan demikian dapat disimpulkan bahwa ada pengaruh yang signifikan antara hasil tes awal dengan tes akhir passing-control sepakbola kelompok metode bagian.

Uji hipotesis ketiga untuk mengetahui perbedaan pengaruh antara metode small sided games dengan metode bagian terhadap hasil belajar passing-control peserta ekstrakurikuler sepakbola MTs Negeri Srono Kabupaten Banyuwangi. Hasil pengujian hipotesis dengan analisis varians satu jalur dilakukan terhadap data selisih hasil belajar passing-control tes akhir antara metode small sided games dan metode bagian.

Berdasarkan hasil perhitungan analisis varian sebagaimana ditunjukkan dalam tabel 
Dyo Rizky Hadi Soekirno, Pengaruh Metode Small Sided Games dan Metode Bagian Terhadap Hasil Belajar Passing-Control Sepakbola

6 diperoleh harga $F_{\text {hitung }}$ 391,32 untuk skor hasil tes passing-control sepakbola lebih besar jika dibandingkan dengan $F_{\text {tabel }}$ 4,30 taraf signifikansi $\alpha=0,05$. Dengan demikian dapat disimpulkan bahwa ada perbedaan pengaruh antara selisih hasil tes passingcontrol sepakbola metode small sided games dengan metode bagian.

\section{PEMBAHASAN}

Hasil pengujian hipotesis per-tama adalah hasil tes keterampilan passingcontrol sepakbola yang dilakukan oleh kelompok eksperimen metode small sided games ternyata ada pengaruh yang signifikan terhadap hasil belajar keterampilan passing-control sepakbola peserta ekstra-kurikuler sepakbola putra MTs Negeri Srono Kabupaten Banyuwangi $F_{\text {hitung }}$ bernilai lebih besar dari pada $F_{\text {tabel. }}$ Berdasarkan hasil perhitungan analisis varian diperoleh $F_{\text {hitung }}$ untuk skor hasil tes passing-control sepak-bola lebih besar jika dibandingkan dengan $F_{\text {tabel }}$ taraf signifikansi $\alpha=0,05$. Dengan demikian dapat disimpulkan bahwa ada pengaruh yang signifikan antara hasil tes awal dengan tes akhir passing-control sepakbola kelompok metode small sided games.

Harsono (1988:100), "Tujuan serta sasaran utama dari pembelajaran adalah untuk membantu atlet atau pemain sepakbola meningkatkan keterampilan dan prestasinya se-maksimal mungkin". Dengan me-lakukan pembelajaran passing-control sepakbola yang sistematis, terstruktur, berulang-ulang, dan jumlah beban pembelajaran kian hari kian meningkat, akan mampu menghasilkan tujuan dari pembelajaran yang dilakukan. Tidak hanya itu, dalam pembelajaran passing-control sepakbola juga memerlukan beberapa aspekaspek yang perlu diperhatikan.

Bondarev (2011:115), "small sided games adalah permainan di lapangan skala kecil merupakan situasi tepat yang dikembangkan untuk peserta ekstrakurikuler sepakbola putra, supaya bisa belajar dan berkembang". Setiap permainan me-rupakan gabungan dari teknik khusus dalam sepakbola, misalnya mengoper, atau melakukan passing bola, atau fokus pada kerja sama tim dan strategi, misalnya bertahan, menye- rang, men-ciptakan ruang gerak, atau bergantian tugas. Didukung dengan jadwal pembelajaran yang sistematis dengan menggunakan intensitas, repetisi, volume serta istirahat yang sesuai maka menghasilkan pengaruh terhadap hasil belajar passing-control dalam permainan sepakbola.

Hasil pengujian hipotesis kedua adalah tes hasil belajar keterampilan passingcontrol peserta ekstrakurikuler sepakbola putra MTs Negeri Srono Kabupaten Banyuwangi usia 13-15 tahun yang dilakukan pada kelompok metode bagian ternyata ada pengaruh yang signifikan terhadap hasil belajar keterampilan passing, Berdasarkan hasil perhitungan analisis varian diperoleh $F_{\text {hitung }}$ untuk skor hasil tes passing-control sepak-bola lebih besar jika dibandingkan dengan $F_{\text {tabel }}$ taraf signifikansi $\alpha=0,05$. Jadi disimpulkan bahwa ada pengaruh yang signifikan antara hasil tes awal dengan tes akhir passing-control sepakbola kelompok metode bagian.

Peningkatan rata-rata hasil belajar keterampilan passing-control sepakbola peserta ekstrakurikuler sepakbola MTs Negeri Srono Kabupaten Banyuwangi kelompok metode bagian meningkat dari sebelumnya.

Thomson (1991:87), "metode bagian merupakan salah satu bentuk pembelajaran yang dapat mening-katkan keterampilan dan kemampuan teknik bermain". Dalam pembelajaran metode bagian ini memberikan pengaruh yang signifikan terhadap hasil belajar passing-control bola peserta ekstrakurikuler sepakbola putra MTs Negeri Srono Kabupaten Banyuwangi usia 13-15 tahun, karena pembelajaran metode bagian mendapatkan porsi belajar khusus yang dapat meningkatkan hasil belajar passing-control sepakbola. Pada saat pembelajaran, proses belajar yang sistematis yang dilakukan secara berulang-ulang yang kian hari kian menambah jumlah beban belajar, terutama untuk meningkatkan hasil belajar passingcontrol sepakbola.

Thomson (1991:87), "metode bagian merupakan salah satu bentuk pembelajaran yang dapat mening-katkan keterampilan dan kemampuan teknik bermain". Dalam pembelajaran metode bagian ini memberikan pengaruh yang signifikan terhadap hasil belajar passing-control bola peserta ekstrakurikuler sepakbola putra MTs Negeri Srono Kabupaten Banyuwangi usia 13-15 tahun, karena 
pembelajaran metode bagian mendapatkan porsi belajar khusus yang dapat meningkatkan hasil belajar passing-control sepakbola. Pada saat pembelajaran, proses belajar yang sistematis yang dilakukan secara berulang-ulang yang kian hari kian menambah jumlah beban belajar, terutama untuk meningkatkan hasil belajar passingcontrol sepakbola.

Hasil uji hipotesis ketiga adalah berdasarkan hasil pengujian hipotesis dengan analisis varian satu jalur antara metode small sided games dengan metode bagian dalam peningkatan hasil belajar passingcontrol pada permainan sepakbola dapat disimpulkan bahwa, metode bagian memberikan pengaruh yang signifikan yang dilakukan selama 18 kali pertemuan (tiga kali dalam satu minggu), hal ini dapat dibuktikan dengan $F_{\text {hitung }}$ lebih besar daripada $F_{\text {tabel }}$ sehingga kesimpulan nihil ditolak. Hal tersebut dapat dibuktikan dengan adanya peningkatan pada rata-rata (mean) yang didapatkan oleh masing-masing kelompok. Pada kelompok small sided games mengalami peningkatan rata-rata (mean), sebesar 21,91 sedangkan kelompok metode bagian mengalami peningkatan rata-rata (mean) sebesar 22,41. Dari data yang diperoleh metode bagian memberikan pengaruh yang signifikan terhadap hasil belajar passingcontrol kepada peserta ekstrakurikuler sepakbola putra MTs Negeri Srono Kabupaten Banyuwangi usia 13-15 tahun, hal itu dikarenakan menurut Thomson (1991:87), "metode bagian menggunakan bagian perbagian dari bagian yang mudah kebagian yang lebih sulit". Pada pembelajaran ketepatan dan akurasi passing-control sepakbola secara tidak langsung keterampilan peserta ekstrakurikuler sepakbola putra MTs Negeri Srono Kabupaten Banyuwangi usia 13-15 tahun dalam melakukan passingcontrol sepakbola akan meningkat, karena ketepatan atau akurasi sangat di-butuhkan dalam melakukan passing-control sepakbola. Hal ini juga didukung dengan menggunakan program pembelajaran yang sistematis, terstruktur dan melakukan secara berulang-ulang, serta memperhatikan intensitas, repetisi, volume dan istirahat atlet yang cukup. Terkait dengan hasil tersebut penelitian terdahulu dari Putra (2015), latihan small sided games terhadap kemampuan
$\mathrm{VO}_{2} \mathrm{MAX}$ pemain sepakbola U-17 di persatuan sepakbola SMUBA junior Kota Batu memberikan pengaruh yang lebih baik dibandingkan latihan konvensional. Hasil penelitian dari Putrantana (2014), Pengembangan Pembelajaran Meroda Menggunakan Alat Bantu dengan Part-WholeMethod pada Siswa Kelas VIII SMP Negeri 18 Malang. Hasil penelitian dari Adiputra (2014), Implementasi Kooperatif Stad Untuk Meningkatkan Aktivitas dan Hasil Belajar Passing Control Sepakbola.

\section{KESIMPULAN}

Berdasarkan pengujian hipo-tesis dan pembahasan dalam penelitian yang dilakukan, maka diperoleh hasil penelitian yang dapat disimpulkan bahwa: (1) Metode small sided games memberikan pengaruh yang signifikan terhadap hasil belajar passingcontrol peserta ekstrakurikuler sepakbola putra MTs Negeri Srono Kabupaten Banyuwangi usia 13-15 tahun. (2) Metode bagian memberikan pengaruh yang signifikan terhadap hasil belajar passing-control peserta ekstrakurikuler sepakbola putra MTs Negeri Srono Kabupaten Banyuwangi usia 13-15 tahun. (3) Metode bagian lebih baik terhadap hasil belajar passing-control dibandingkan metode small sided games peserta ekstrakurikuler sepak-bola putra MTs Negeri Srono Kabupaten Banyuwangi usia 13-15 tahun.

\section{SARAN}

Berikut saran dari peneliti: (1) Kepada pembina ekstrakurikuler sepakbola putra MTs Negeri Srono Kabupaten Banyuwangi sebaiknya menggunakan metode small sided games dan metode bagian yang telah diteliti, karena terbukti pembelajaran ini memberikan pengaruh terhadap hasil belajar passing-control peserta ekstrakurikuler sepakbola putra MTs Negeri Srono Kabu-paten Banyuwangi usia 13-15 tahun. (2) Kepada peserta ekstra-kurikuler sepakbola putra MTs Negeri Srono Kabupaten Banyuwangi usia 13-15 tahun yang menjadi sampel penelitian ini diharapkan terus me-lakukan metode small sided games dan metode 
Dyo Rizky Hadi Soekirno, Pengaruh Metode Small Sided Games dan Metode Bagian Terhadap Hasil Belajar

bagian secara terencana dan terprogam, sehingga peserta ekstra-kurikuler sepakbola putra dapat meningkatkan hasil belajar passing-control sepakbola. (3) Metode bagian dapat digunakan sebagai bentuk pembelajaran yang bertujuan untuk meningkatkan ketepatan, keterampilan untuk meningkatkan hasil belajar passing-control dalam permainan sepakbola.

\section{DAFTAR PUSTAKA}

Al-Hadiqie, Z. M. 2013. Menjadi Pemain Sepakbola Profesional. Bandung: Kata Pena.

Bondarev D. V. 2011. Factors influencing cardiovascular responses during small-sided soccer games performed with recreational purposes. Physical education students, No 2: hal. 115, (Online),

(https://6164e0b7cb2ea3fd2262d051 4d0a2d1abd1968af.googledrive.com/ host/0B9e-88VRcw-

YVE9haVltbmN6eFU/html/journal/20 11-N2/11bdvwrp.pdf), diakses 25 januari 2016.

Budiwanto, S. 2011. Metodologi kepelatihan olahraga. Malang: UM Press.

Coerver, W. 1987. Sepakbola Program Pembinaan Pemain Ideal. Jakarta: PT Gramedia.

Hariyoko. 2012. Pengembangan Model Pembelajaran Keterampilan Dasar Sepakbola Peserta Ekstrakulikuler Sepakbola SMP Negeri di Kota Malang. Disertasi tidak diterbitkan. Jakarta: PPs UNJ.

Harsono. 1988. Coaching dan Aspek-aspek Psikologis Dalam Coaching. Jakarta: PT Raja Grafindo Persada.

Luxbacher, J. A. 2004. Sepak Bola. Jakarta: PT Raja Garfindo Persada.

Mielke, D. 2009. Dasar-Dasar Sepakbola. Bandung: Pakar Raya.
Nurrochmah S, 2005. Prosedur Analisis Uji Persyaratan Dalam Statistika Inferensial. Laboratorium IImu Keolahragaan Fakultas IImu Keolahragaan Universitas Negeri Malang.

Putra, A. U. K. 2015. Pengaruh Latihan Small Sided Games terhadap Peningkatan Kemampuan $\mathrm{VO}_{2} \mathrm{MAX}$ Pemain Sepakbola U-17 Persatuan Sepakbola SMUBA Junior Kota Batu. (Online), (journal.um.ac.id/index.php/pendidika n-jasmani/article/view/4886), diakses 25 januari 2016.

Rosdiani, D. 2013. Perencanaan Pembelajaran dalam Pendidikan Jasmani dan Kesehatan. Bandung: ALFABETA.

Sudaryono \& A. Saefullah. 2010. Statistik Deskriptif Langkah Mudah Analisis Data. Yogyakarta: Andi Yogyakarta.

Sugiyono. 2013. Metode Penelitian Kuantitatif Kualitatif dan $R \& D$. Bandung: Alfabet.

Sukmadinata, N. S. 2013. Metode Penelitian Pendidikan. Bandung: PT Remaja Rosadakarya.

Suyono. \& Hariyanto. 2011. Belajar dan Pembelajaran. Bandung: PT Remaja Rosadakarya.

Thompson. 1991. Pengenalan Kepada Teori Kepelatihan. Terjemahan oleh Hasan. 1993. Jakarta: Progam Pendidikan \& Sistem Sertifikasi Pelatih Atletik PASI.

Widijoto, H. dkk. 2010. Buku Petunjuk Teknis Praktik Pengalaman Lapangan Bidang Studi Pendidikan Jasmani. Malang: Universitas Negeri Malang. 